\title{
Research on Cultivation of Creative Humanistic Quality in the Teaching Course of Food Biochemistry
}

\author{
Xingli Zhang \\ Qilu University of Technology, School of Food Science and Engineering, Jinan 250353, Shandong, China. E-mail: \\ xlzhang227@163.com \\ Fund Project: Construction Project of Core Curriculum Group of Qilu University of Technology(40012712); Research project \\ of teaching reform of undergraduate course colleges and universities in Shandong Province(M2018X072).
}

\begin{abstract}
Food science is a discipline of blending culture, art and science. Food science is not only a complicated systematic discipline but also a dual-attribute science with natural science and humanistic sociality. Therefore, an excellent food talent needs not only solid professional basic knowledge but also excellent humanistic qualities and humanistic spirit. The food biochemistry is a more important professional core course in the food professional education. The integration of humanistic quality education into the teaching of food biochemistry plays a very important guiding role for students' subsequent development. Based on the teaching practice for many years, this article expounds the connotation of humanistic quality, the goal of humanistic quality education and some ways to implement humane quality training in food biochemistry teaching.
\end{abstract}

Keywords: Food Biochemistry; Humanities; Quality Education

Food biochemistry is a very important professional core course in the majors of wine-making, food science and engineering, food quality and safety and other food-related majors. It is both a basic subject of food science and a cuttingedge discipline with the most rapid development and dynamic frontier subject in the natural science. Food biochemistry is the earliest professional basic course that the students of food majors learned after they enter the university. It is an important foundation for students to further learn professional class, is also one of the subjects for the preliminary examination of the postgraduate examination. Learning food biochemistry well will build a good confidence for students to further study professional knowledge in the future.

\section{Humanities education for food students}

\subsection{Connotation of humanities in food majors}

For the students of food specialty, their humanistic quality includes two aspects: solid food professional knowledge and humanistic spirit cultivation that they need to master when they are engaged in food work. More specifically, they gradually integrated and accumulated good social responsibility, professional ethics, behavioral self-cultivation and corresponding moral character through the study of food professional knowledge and human liberal education.

In view of the current situation of food industry in China, food safety problems keep cropping up. Food workers should not only solve the problem of people's food, but also pay attention to food safety, meet the needs of individuals to the greatest extent. The humanistic literacy of food students mainly includes good social responsibility, excellent team cooperation ability

Copyright(C 2020 Xingli Zhang

doi: 10.18686/ahe.v4i10.2944

This is an open-access article distributed under the terms of the Creative Commons Attribution Non-Commercial License (http://creativecommons. org/licenses/by-nc/4.0/), which permits unrestricted non-commercial use, distribution, and reproduction in any medium, provided the original work is properly cited. 
and solid professional skills. It is the most important is that the students in food majors should have the sense of innovation, independent learning ability and life-long learning ability.

\subsection{The goal of humanities education for food students}

The goals of the humanistic quality education in food major are as follows: First, the teachers should uphold the concept of "safety first in food", that is, to train students to follow through the value idea of "safety" in their studies and future work; second, they should attach importance to the education idea of "people-oriented" and cultivate students' sense of social responsibility in their future work and study; the last, in consideration of complexity of education and teaching, the students of food major will face the complex social natural person whose demand for food is different, so we should cultivate the students' innovative ability. Teachers should combine these characteristics and integrate the humanities liberal education into the teaching course of food biochemistry in accordance with the goals of these liberal education. In addition to teaching students to master solid basic theoretical knowledge, teachers should also focus on cultivating students' good professional ethics, sound personality and social morality.

\section{Cultivating the creative ability of food students}

\subsection{The connotation of innovation ability in food}

Today, the development of food is very fast. Whether it is theoretical basis or actual food technology, it is constantly communicating with other natural disciplines, which makes contemporary food show a highly integrated and innovative comprehensive development trend. Therefore, in the learning process, food students should not only be proficient in the knowledge theory of the major, but also strengthen their cultivation of innovative ability, constantly learn more new knowledge, learn to analyze the food theory from different angles, and form good Innovative thinking ability.

Food Science is a subject with integrating culture, science and art. Nowadays, the food industry is developing with each passing day. Whether it is basis theory knowledge, actual food design, testing technology or processing technology, it is constantly communicating with other natural disciplines, which makes contemporary food shows a highly cross-cutting and innovative comprehensive development trend. Therefore, in the learning process, the students of food major should not only master the professional theoretical knowledge, but also strengthen the cultivation of their own innovative ability, constantly learn more new knowledge, learn to analyze and solve problems from different angles, and form good innovation thinking ability.

\subsection{The goal of cultivating innovative ability of food students}

One of the training goals of the students of food science is to cultivate high-quality applied talents with innovative consciousness, which shows the importance of innovative ability to the cultivation of talents. The cultivation goal of food students' innovation ability can be mainly divides into the following three points. Firstly, teachers should establish the positive study environment, train the student's innovation thinking and innovation ability. Secondly, they should continuously cultivate more professional talents with critical spirit and innovative spirit, while ensuring students' basic food professional knowledge, and constantly strengthen students' innovative practical ability to enhance students' ability to adapt to complex environment. Lastly, they should urge students to combine innovative ability with their excellent traditional moral and cultural cultivation, improve their comprehensive professional quality, sense of social responsibility and professional ethics. With the above measures conducted, the teachers can cultivate a batch of high-level, high-quality application-oriented food professionals according to training objective.

\section{Several ways to implement humane quality training in biochemistry teaching}

\subsection{Strengthen the role of teachers as role models and improve teachers' humanities}

Teacher moral culture and teacher moral education is a very important way of humane quality education. Schools should pay attention to the influence of teachers' qualities in education and teaching, and establish a good teaching role model. Only by setting an example by teachers and constantly maintaining the improvement and progress of their humanities can teachers really improve the quality of humanities and cultivate the quality and efficiency of teaching. Therefore, based on this 
teaching concept, schools should actively carry out various educational activities which promote the improvement of teachers' humanistic qualities. For example, schools can carry out a series of educational activities that focus on typical navigation and cultivate teachers' ethics, and establish good teacher cultural literacy cultivate the environment, comprehensively improve the use of teachers' role models, and lay a good foundation for the cultivation of students' good humanities.

\subsection{Change the teaching concept to improve the humanistic quality of teachers}

The concept of "moral education and cultivate people" is put forward for the first time in the 18th Congress of the Communist Party of China. Because world outlook, outlook on life and values are the core and symbol of people's cultural accomplishment, the concept of "moral education and cultivate people" is a fundamental task of education, that is to say that cultivating socialist builders and successors is important tasks of education. It not only pointed out the direction of educational reform, but also highlighted the importance of teachers' morality and style in education. Teachers' morality and style are very important ways of humanistic quality education. Excellent teachers' morality has great influence on education and teaching, and can set a good example for students.

Only by setting an example and keeping the promotion and progress of their own humanistic quality, teachers can really improve the quality of students' humanistic quality cultivating. Therefore, based on this educational idea, Qilu University of Technology has actively carried out various teaching activities to promote the improvement of teachers' humanistic qualities. For example, our college has conducted teaching selection activity, such as "moral integration good teaching plan", "moral integration good class" and "moral integration good teacher", established a good environment for the cultivation of teachers' cultural quality, promoted the use of teachers' role models in an all-round way, and lay a good foundation for the cultivation of students' humanistic quality.

\subsection{Reform teaching methods to stimulate students' interest in learning}

Food Biochemistry is one of the most important core course of food-related specialty. Because of many basic knowledge to master and remember, the traditional boring teaching method can't effectively promote students' learning interest, so that the students have the fear of difficulties in the study process of food biochemistry and study efficiency is very low. Therefore, teachers should fully carry out relevant teaching research activities, constantly reform teaching methods, listen to students' opinions and choose more suitable teaching strategies, so as to improve the teaching effect and teaching quality of food biochemistry.

In the teaching process of food biochemistry, teachers should fully respect the principal position of students and improve the teaching effectiveness of food biochemistry by adopting the teaching methods of discussion and interaction. In addition, teachers can also make full use of national and provincial mass online open courses and other network teaching resources, broaden the content of food biochemistry teaching, and improve students' learning enthusiasm and initiative. The comprehensive use of various teaching methods can't only improve students' interest in learning, but also effectively improve students' team spirit, which is of great help to the improvement of students' humanistic quality.

\subsection{Cultivating students' innovative consciousness and improve humanistic spirit}

The cultivation of students' innovative ability is the ultimate goal of higher education. In teaching practice, teachers have encouraged students to apply for projects "Innovation and Entrepreneurship Training Program for university students", instructed students to form a team, wrote the application, designed the experiment, wrote the thesis and concluded projects. Because food science spans many disciplines, including chemistry, food, biology, engineering technology, and processing machinery. Building a team need coordinate across different disciplines and colleges, which improve students' communication ability. In the process of writing application and designing experiment, the students must multi-party cooperate, which increases the students' ability of unity and cooperation, and effectively improves the students' humane quality and comprehensive quality. In recent years, the teachers of the biochemistry teaching team have guided students to declare the project and obtain 5 projects of innovative entrepreneurship training program for college students at all levels. Nearly 30 students have participated in the team-building and cooperative research, which has led to a learning atmosphere in the class, cultivate students' innovative thinking. 


\subsection{Integrated the elements of "ideological and political" to improve students' sense of social responsibility and public morality}

Food Biochemistry is famous for numerous knowledge points and abstract contents. Because the course contents are boring and difficult to understand, students are somewhat afraid of the complicated theoretical knowledge. If teachers follow the traditional "full-filling" teaching method, it is easy to lead students to be tired of learning, which directly affects the teaching quality and teaching effect of food biochemistry. Teachers can not only enliven the dull classroom atmosphere, but also make the boring teaching content interesting by properly adding some humanistic knowledge related to food biochemistry, which effectively enhances the student's learning enthusiasm and interest. For example, when explaining the content of protein, the teachers should add knowledge about melamine. From the structural characteristics of melamine to explain why the addition of melamine in milk powder can increase the nitrogen content of protein, melamine harm to the human body, etc. The teachers used real events to teach students that they must strictly abide by food laws and regulations, warn students that they must never, in future work, illegally add harmful substances to food for profit, and teach students to establish core socialist values.

\subsection{Make full use of "internet + " to further promote students' humanistic spirit}

With the rapid development of the "internet", various industries have been rejuvenated. The integration of information network technology and food specialty education can effectively promote the reform of teaching methods, which has great advantages in infiltrating the cultivation of humanistic quality and students' moral education. For example, teachers can take advantage of the convenient network platform to push some learning resources related to food biochemistry to students to improve their humanistic quality, so as to promote the cultivation of students' humanistic quality in a subtle way. In addition, teachers can also use timely communication tools such as WeChat and QQ, invite experienced workers and practitioners of the food industry to communicate with students online, solve students' confusion in learning, let students experience the future working environment and the way ahead of schedule, and improve students' ability to communicate with others at the same time. Only by undergoing these measures, can the students enhance learning enthusiasm, and improve the teaching quality and teaching effect of food biochemistry in turn stretches.

\section{Conclusion}

In summary the humanistic quality cultivation is indispensable in the education of food-related specialty. Food biochemistry is one of the most important core courses in the early stage of food major. The integration and penetration of humanistic quality education in the teaching process can play a positive role in stimulating students' learning interest, cultivating students' innovative thinking, standardizing students' behavior habits, and improving teachers' teaching quality. Teachers should pay more attention to the teaching practice of strengthening the cultivation of humanistic quality in the teaching process of food biochemistry, pay attention to the development of students' social responsibility, innovative ability and independent learning ability, and cultivate more high-quality application-oriented food professionals for the nation and society.

\section{References}

1. Li L. Important role in promoting social competitiveness and its teaching strategies of humanistic quality education in colleges and universities. Survey of Education 2019; 8(7): 54-55+116.

2. Ma H, Hou J, Luo J, et al. Research on cultivation of creative humanistic quality in the teaching course of food biochemistry. China health industry 2018; (04): 121-122.

3. Wang B, Du C. Research on the biochemical experiment model based on the application of innovative talents training. Chemical Engineering Management 2018; (014): 16-17.

4. Hou J, Zhang W, Fan H, et al. Construction of formative assessment system in biochemistry and molecular biology teaching. China Educational Technique \& Equipment 2015; (16): 124-125. 